\section{Protocols for Trapping Internal and 3'-Terminal Exons}

\author{
Paul E. Nisson, ${ }^{1}$ \\ Abdul Ally, and \\ Paul C. Watkins ${ }^{2}$ \\ ${ }^{1}$ Life Technologies, Inc., \\ Gaithersburg, Maryland 20884-9980; \\ ${ }^{2}$ Sequana Therapeutics, \\ La Jolla, California 92037
}

The cloning of genes on the basis of their genetic map positions (positional cloning) has proven to be a powerful tool in the growing field of gene discovery. ${ }^{(1)}$ The list of heritable human disease genes successfully isolated by using this strategy is rapidly expanding. Positional cloning can be described as a four-step process: (1) finding genetic linkage between a disease phenotype and genetic markers of known map position; (2) obtaining this region as a set of physically overlapping pieces of cloned DNA using cosmid, P1, P1 artificial chromosome (PAC), bacterial artificial chromosome (BAC), or yeast artificial chromosome (YAC) clones; ${ }^{(2-6)}$ (3) screening the set of overlapping clones (known as a contig) for expressed sequences; and (4) using these captured bits of expressed sequence to identify a full-length cDNA clone and the mutation that distinguishes the normal from the mutant allele associated with the genetic disease. Because genetic and physical maps of the human genome are being developed rapidly, perhaps the most difficult part of the positional cloning strategy is the actual isolation of candidate genes from the mapped region. Several methods exist to screen genomic clones for expressed sequences, including multispecies blotting, cDNA library screening, and CpG island identification; however, direct cDNA selection and exon trapping are becoming the preferred methods. ${ }^{(7-18)}$ Direct cDNA selection usually captures larger bits of expressed sequence than does exon trapping, but it requires a high-quality cDNA source (primary cDNA or cDNA library) in which the gene of interest is expressed. ${ }^{(10,11)}$ Exon trapping, however, extracts exons directly from cloned genomic DNA without the need for cDNA. For this reason, exon trapping can be considered to be a very useful tool for gene discovery and transcript mapping because the selection for expressed sequences is based solely on the presence of splicing recognition sequences. Methods are presented here for the isolation of internal and 3'-terminal exons from YACs and cosmids containing cloned human DNA.

\section{TRAPPING INTERNAL EXONS USING PSPL3-OVERVIEW}

The exon trapping vector pSPL3 is an improved version of the plasmid pSPL1 developed by Buckler and colleagues. ${ }^{(12,13)}$ pSPL3 (Fig. 2, below) contains a multiple cloning site and other modifications that result in a reduction of cryptic splicing as well as a higher transfection efficiency as a result of the incorporation of restriction enzyme (BstXI) half-sites flanking the splice donor and acceptor sites of pSPL3. ${ }^{(13)}$ Although most published reports on exon trapping have used cosmids as substrates, ${ }^{(13,19)}$ at least one paper has described a method for trapping exons from YACs. ${ }^{(20)}$ We have focused on using pSPL3 for exon trapping YACs, highlighting their special requirements.

A flow diagram describing the internal exon-trapping procedure for YACs is shown in Figure 1: A YAC clone is propagated, and DNA is purified after pulsed-field gel electrophoresis, then digested, and subcloned into the plasmid pSPL3. The subclones are then propagated in Escherichia coli and arrayed in pools. After miniprep DNA is made from subclone pools, the DNA is transfected into COS-7 cells. After transient expression, the RNA is harvested and first-strand cDNA is reverse-transcribed using a vector-specific oligonucleotide. Following digestion of the RNA template by $\mathrm{RNase} \mathrm{H}$, an initial round of PCR is performed; BstXI is then added resulting in the removal of PCR products that do not contain exons. A second round of PCR is performed, followed by rapid cloning into a phagemid vector using uracil DNA glycosylase. ${ }^{(21)}$ The following sections describe the details of each step.

\section{Purification and Preparation of YAC DNA for Subcloning into the Exon-Trapping Vector pSPL3}

By encapsulating yeast cells in agarose beads prior to treatment with yeast lytic enzyme and lysis buffers, YAC DNA is protected from the shear forces 

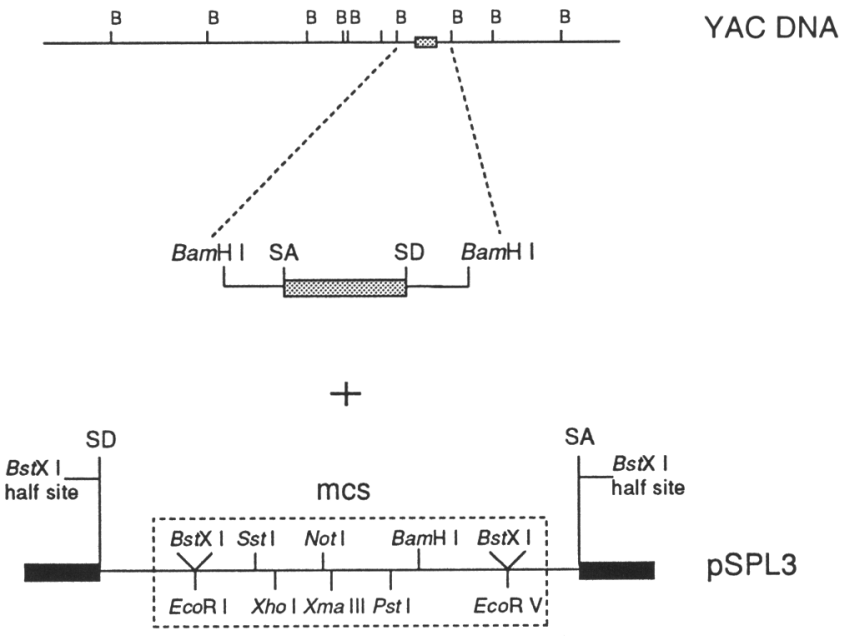

pSPL3

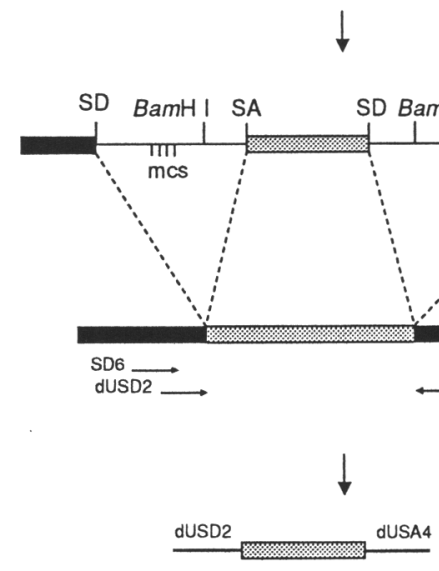

Subcloned DNA

RNA after

splicing

Trapped exon after PCR

FIGURE 1 pSPL3 exon trapping of YAC or cosmid DNA. YAC DNA is digested with a restriction enzyme, e.g., BamHI (B). In this example, a single exon (shaded box) is contained in a BamHI fragment. The exon is flanked by splice acceptor (SA) and splice donor (SD) sites. The pSPL3 vector is prepared for subcloning at the same restriction site. The MCS of pSPL3 contains several restriction enzyme sites. The EcoRI and EcoRV sites are contained within BstXI sites. The solid boxes represent HIV-tat and rabbit $\beta$-globin exon sequences in the pSPL3 vector. The splicing donor and acceptor sites of pSPL3 contain BstXI half-sites. These sites form a complete BstXI site after splicing events occur that fail to capture a "trapped" exon and can therefore be used to eliminate vector background in the subsequent PCR. After subcloning genomic DNA into pSPL3, DNA is isolated and transfected into COS-7 cells. Total RNA is isolated for RNA-based PCR analysis. After generation of CDNA, the first round of PCR is performed using the outside primer pair SD6 (TCT GAG TCA CCT GGA CAA CC) and SA2 (ATC TCA GTG GTA TTT GTG AGC). A second round of PCR is performed using the nested primers dUSD2 (CUA CUA CUA CUA GTG AAC TGC ACT GTG ACA AGC TGC) and dUSA4 (CUA CUA CUA CUA CAC CTG AGG AGT GAA TTG GTC G) to provide specificity and to install DNA sequences that allow UDG cloning of the PCR products. Trapped exons are recognized after gel analysis of the PCR products. Occasional but infrequent use of the cryptic splice donor site can be detected by digestion with NdeI.

associated with manipulations required in this procedure. Because the yeast chromosomes are enclosed in very small agarose beads, the material is easily pipetted. Following pulsed-field gel electrophoresis and isolation of YAC DNA using $\beta$-agarase, the purified YAC is an ideal high-molecular-weight substrate for partial or complete restriction enzyme digestion.

1. Inoculate $200 \mathrm{ml}$ of $\mathrm{AHC}$ broth with $10 \mathrm{ml}$ of an overnight culture started from a single colony from a freshly grown AHC plate or from a small amount of material from a frozen glycerol stock. 
2. Incubate culture for $24 \mathrm{hr}$ at $30^{\circ} \mathrm{C}, 200 \mathrm{rpm}$, in a shaking incubator.

3. Decant culture into two $50-\mathrm{ml}$ sterile polypropylene centrifuge tubes and pellet the cells by centrifuging for $10 \mathrm{~min}$ at $1600 \mathrm{~g}$ at room temperature. Note: While the cells are being pelleted, prepare the following: bath.

a. Prewarm a $50-\mathrm{ml}$ sterile polypropylene centrifuge tube in $45^{\circ} \mathrm{C}$ water

b. Prepare $10 \mathrm{ml}$ of a $1 \%$ solution of low-melting-temperature agarose in SE buffer ( $75 \mathrm{mM} \mathrm{NaCl}, 25 \mathrm{~mm}$ EDTA at $\mathrm{pH} 8.0)$, and equilibrate in $45^{\circ} \mathrm{C}$ water bath.

c. Equilibrate $25 \mathrm{ml}$ of light mineral oil in $45^{\circ} \mathrm{C}$ water bath. Equilibrate $100 \mathrm{ml}$ of SE buffer in a $250-\mathrm{ml}$ glass beaker containing a stir bar to $4^{\circ} \mathrm{C}$ by placing the beaker in an ice bucket containing a slurry of ice and water. Place this on a stir plate set to medium speed. Allow at least $10 \mathrm{~min}$ for equilibration of the SE buffer to $4^{\circ} \mathrm{C}$.

4. Wash cells three times with $10 \mathrm{ml}$ of SE buffer. Centrifuge cells for 5 min at $1600 \mathrm{~g}$ at room temperature.

5 . Resuspend combined yeast cell pellets in a total of $4 \mathrm{ml}$ of SE buffer.

6. Add yeast cell suspension to a prewarmed 50-ml sterile polypropylene centrifuge tube in the $45^{\circ} \mathrm{C}$ water bath. Incubate for $3-5 \mathrm{~min}$.

7. Add $2.5 \mathrm{ml}$ of $1.5 \%$ low-melting-temperature agarose in SE buffer $\left(45^{\circ} \mathrm{C}\right)$ to the yeast cell suspension. Gently swirl to mix.

8. Add $12 \mathrm{ml}$ of light mineral oil $\left(45^{\circ} \mathrm{C}\right)$ to the yeast cell suspension. Shake the tube back and forth vigorously for $5 \mathrm{sec}$ to form an emulsion.

9. Steadily pour the emulsion into the cold SE buffer $\left(100 \mathrm{ml}\right.$ at $\left.4^{\circ} \mathrm{C}\right)$ while stirring (do not pour into the vortex-pour just inside the beaker. The bead size is influenced by temperature and degree of swirling. Faster swirling and increasing the temperature of the SE buffer from $4^{\circ} \mathrm{C}$ to $9^{\circ} \mathrm{C}$ will result in smaller beads).

10. Stir for $5 \mathrm{~min}$. Transfer to two $50-\mathrm{ml}$ centrifuge tubes and centrifuge for $10 \mathrm{~min}$ at $1600 \mathrm{~g}$ at room temperature.

11. Remove mineral oil from the top of each tube with a pipette. Disperse bead pellet (both at the bottom of the tube and immediately below the mineral oil layer at the top) by pipetting through a 1-ml pipette tip after removing a few millimeters from the tip with a razor blade to increase the bore size.

12. Centrifuge again. Remove supernatant with a pipette. Combine agarose bead pellets using a large-bore pipette tip prepared as described above.

13. Centrifuge once more. Remove any remaining supernatant.

14. Add to the agarose bead pellet $0.5 \mathrm{ml}$ of $\beta$-mercaptoethanol, $0.5 \mathrm{ml}$ of $\mathrm{SE} / y e a s t$ lytic enzyme (YLE) solution ( $5 \mathrm{mg}$ of $\mathrm{YLE} / \mathrm{ml}$ in SE buffer), and adjust the volume to $10 \mathrm{ml}$ with SE buffer (for a final concentration of $35 \mathrm{U} / \mathrm{ml}$ of YLE). Disperse beads and incubate for $2 \mathrm{hr}$ at $37^{\circ} \mathrm{C}$.

15. Centrifuge tubes for $10 \mathrm{~min}$ at $1600 \mathrm{~g}$ at room temperature.

16. Remove supernatant with pipette. Resuspend in $10 \mathrm{ml}$ of proteinase buffer [ $1 \%$ sarcosyl (wt/vol), $25 \mathrm{mM} \mathrm{Na}{ }_{2}$ EDTA (pH 8.0), $500 \mathrm{mg} / \mathrm{ml}$ of proteinase $\mathrm{K}]$, and incubate for $18 \mathrm{hr}$ at $50^{\circ} \mathrm{C}$.

17. Centrifuge for $10 \mathrm{~min}$ at $1600 \mathrm{~g}$ at room temperature. Remove the supernatant with pipette. Resuspend bead pellet in ET buffer (50 mM EDTA, 10 $\mathrm{mm}$ Tris at $\mathrm{pH} 8.0$ ).

18. Centrifuge again, and resuspend the beads in $10 \mathrm{ml}$ of ET buffer containing 0.1 mM PMSF.

19. Centrifuge again; wash twice in $10 \mathrm{ml}$ of ET buffer before storing at $4^{\circ} \mathrm{C}$.

Pulsed-Field Gel Electrophoresis of YAC DNA

A YAC will, in most cases, be distinguishable from the yeast chromosomes 
after electrophoresis and staining with ethidium bromide. In those cases where the YAC comigrates with a yeast chromosome, a human or mouse YAC can be detected and sized by transferring the pulsed-field gel to a nylon membrane and hybridizing it with labeled high-molecular-weight human or mouse Cot-1 DNA (Life Technologies/GIBCO-BRL cat. nos. 18376-012 and 18440-016, or contact Life Techologies, Inc., for more information). YAC DNA can be purified after pulsed-field gel electrophoresis in the following manner: A sample of beads prepared as described above can be electrophoresed using $1 / 2 \times$ TBE buffer, at $200 \mathrm{~V}$, with a switch time of $20 \mathrm{sec}$ in a $1 \%$ LMP-agarose gel for $24 \mathrm{hr}$ to resolve a YAC in the $250-\mathrm{kb}$ size range from neighboring yeast chromosomes. The switch time can be altered to suit the separation requirements: longer times for resolving larger YACs and shorter times for smaller YACs. After electrophoresis, the YAC band is cut out of the gel and purified as follows:

1. Cut out the YAC from the pulsed-field gel with a clean scalpel.

2. Add 1 volume of $1 \times$ agarase buffer $(10 \mathrm{~mm}$ bis-Tris- $\mathrm{HCl}$ at $\mathrm{pH} 6.5,1 \mathrm{~mm}$ EDTA) to the gel slice. Incubate at room temperature for $30 \mathrm{~min}$.

3. Remove liquid from gel slice and add $\mathrm{NaCl}$ to $100 \mathrm{~mm}$. Melt at $65^{\circ} \mathrm{C}$ for $10 \mathrm{~min}$. Measure volume; place at $45^{\circ} \mathrm{C}$ for $5 \mathrm{~min}$.

4. Add $1 \mu \mathrm{l} \beta$-agarase $\mathrm{I} / 200 \mu \mathrm{l}$ liquified gel solution, and mix thoroughly (Life Technologies/GIBCO-BRL, cat. no. 10195-014). Place at $40^{\circ} \mathrm{C}$ for $1-2 \mathrm{hr}$.

5. Place tube on ice for $10 \mathrm{~min}$, then centrifuge at $12,000 \mathrm{rpm}$ for $5 \mathrm{~min}$ to pellet any undigested agarose.

6 . Remove supernatant to a new tube, add 0.5 volume of ammonium acetate (or 0.1 volume $3 \mathrm{~m}$ sodium acetate) and 0.8 volume of isopropanol. Place on ice for $1 \mathrm{hr}$ and centrifuge at $12,000 \mathrm{~g}$ at $4^{\circ} \mathrm{C}$ for $20 \mathrm{~min}$ to pellet DNA. Alternatively, incubation overnight at $4^{\circ} \mathrm{C}$ may be preferred if the amount of DNA being precipitated is present in low amounts, that is, $<0.1 \mu \mathrm{g}$.

7. Wash the pellet with $500 \mu \mathrm{l}$ of $70 \%-20^{\circ} \mathrm{C}$ ethanol, and centrifuge the tube for $5 \mathrm{~min}$ in a microcentrifuge.

8. Decant ethanol. Add TE to pellet and let sit at room temperature for $1 \mathrm{hr}$ to allow DNA to dissolve (especially if fragments are $>100 \mathrm{~kb}$ ) or overnight at $4^{\circ} \mathrm{C}$.

\section{Preparing YAC and pSPL3 DNA for Subcloning}

1. Digest the YAC and PSPL3 DNA with the same or compatible restriction endonucleases. There are a large number of unique restriction enzyme sites within the multiple cloning sites (MCS) of pSPL3 (Fig. 2) enabling a great deal of flexibility in choice of cloning site.

2. Phenol-extract YAC and pSPL3 DNA after restriction digestion: Add 1 volume of phenol/chloroform/isoamyl alcohol (25:24:1), vortex, and centrifuge at room temperature for $2 \mathrm{~min}$ at $12,000 \mathrm{~g}$ to separate the phases. Carefully remove the upper aqueous phase and transfer to a fresh microcentrifuge tube.

3. Precipitate the DNA with 0.5 volume of $7.5 \mathrm{M}$ ammonium acetate and 2 volumes of absolute ethanol, mix, hold on wet ice for $20 \mathrm{~min}$, microcentrifuge for $30 \mathrm{~min}$, wash with $70 \%$ ethanol, air dry, and resuspend each in TE. Resuspend a gel's worth of YAC DNA in no more than $10 \mu l$ (the yield per gel will vary from 1 to $3 \mu \mathrm{g}$, depending on the gel width and thickness).

4. Dephosphorylate the linearized pSPL3 DNA using calf intestinal alkaline phosphatase and supplier's recommendations.

\section{Shotgun Subcloning of YAC DNA into pSPL3}

1. Add distilled water to the following components for a final volume of 5 


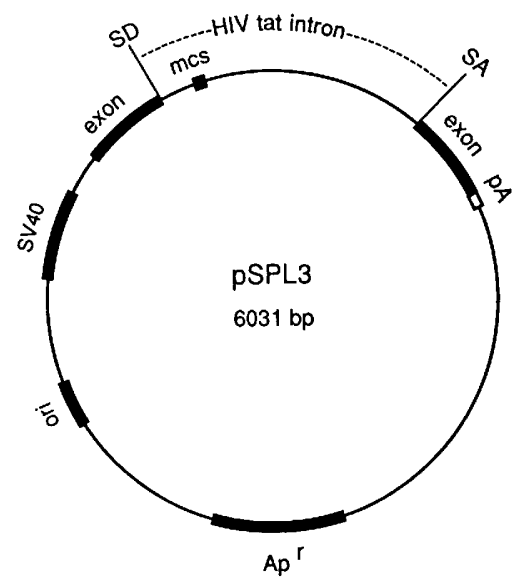

FIGURE 2 Map of pSPL3. The vector contains sequences that enable replication in $E$. coli and COS-7 cell hosts (bacterial and SV40 origins of replication are present). An ampicillin resistance marker $\left(\mathrm{Ap}^{\mathrm{r}}\right)$ allows for selection of subclones. An MCS that interrupts the HIV-tat intron provides several restriction sites for the subcloning of genomic DNA. After transfection of COS-7 cells, transcription occurs at high levels facilitated by the SV40 promoter (SV40). Processing of the transcript results in removal of the HIV-tat intron via splicing in which the vector exons (which contain sequences from HIV and rabbit $\beta$-globin) are combined at the splice donor (SD) and splice acceptor (SA) sites. Cytoplasmic RNA is polyadenylated [pA $=\mathrm{SV} 40$ poly(A) addition recognition sequence]. Exons are trapped from genomic DNA cloned into pSPL3 as a result of interaction of the vector splice sites (derived from HIV-tat) with splice sites flanking exons contained in genomic DNA.

$\mu \mathrm{l}$ : 5-10 ng of pSPL3 restriction enzyme-digested DNA; $10 \mathrm{ng}$ of restriction enzyme-digested YAC DNA; $1 \mu l$ of $5 \times$ T4 DNA ligase buffer (Life Technologies/GIBCO-BRL cat. no. 15224-017); $0.5 \mu$ l (at least 0.5 unit ) of T4 DNA ligase (Life Technologies/GIBCO-BRL cat. no. 15224-017). Include a control (all the above components without genomic DNA) to assess the level of vector self-ligation.

2. Mix gently and incubate for $1 \mathrm{hr}$ at room temperature.

3. Transform $E$. coli with the ligated DNA using either chemically or electrocompetent cells.

4. Recover at least 500 colonies for every $100 \mathrm{~kb}$ of YAC complexity (by adding medium to the transformation plate and using a glass spreader in a circular motion). Isolate DNA by the alkaline lysis procedure. ${ }^{(22)}$ The efficiency of the shotgun subcloning can be assessed by cutting the DNA with the same restriction enzyme that was used to subclone it and comparing the digested source DNA by performing a "Cotblot" (P.E. Nisson and P.C. Watkins, unpubl.). The digested YAC and the pSPL3 library DNA is electrophoresed , transferred to a filter, and hybridized with labeled high-molecularweight human Cot-1 DNA. If the hybridization pattern of the digested pSPL3 library DNA and the digested YAC DNA are similar, this would indicate that most of the YAC is represented in the pSPL3 library. In addition, the frequency of recombinants can be qualitatively determined by digesting the library DNA with PvuII, which cuts pSPL3 twice, yielding a 1.8- and a 4.2-kb band. The MCS is embedded within the 1.8-kb band (Fig. 2). The presence of an intense $4.2-\mathrm{kb}$ vector band, together with a variety of other bands along with the absence of a strong $1.8-\mathrm{kb}$ band, indicates that the nonrecombinant frequency is quite low.

5. Plate 0.1 and $0.01 \mathrm{ml}$ of each transformation on LB plus ampicillin plates to assess the degree of vector religation. Repreparation of dephosphorylated vector is recommended if $>10 \%$ of the transformants are vector religations. 


\section{IIIIIIManual Supplement}

\section{Transfection of CoS-7 Cells}

COS-7 cells, a commonly used tissue culture cell line, have a doubling time of $\sim 20 \mathrm{hr}$. When ordered from the ATCC (CRL-1651), the cells are frozen and should be passaged at least once to establish the appropriate doubling time. A T-70 flask of COS-7 cells is maintained and passaged by trypsinizing the cells and diluting them 1:50 in fresh medium whenever they reach $100 \%$ confluence (once or twice each week). Although electroporation can be used to introduce the genomic DNA subcloned in pSPL3 into COS-7 cells, transfection with the cationic lipid LipofectACE (Life Technologies/GIBCO-BRL cat. no. 18301-010) has been found to be comparable in efficiency and less costly in time and materials. ${ }^{(23)}$ Positive and negative (no DNA) transfection controls are recommended. A positive control plasmid containing an internal exon is included in the Life Technologies Exon Trapping System mentioned above.

1. Add $3 \times 10^{5}$ to $5 \times 10^{5}$ COS-7 cells in supplemented DMEM (Dulbecco's modified Eagle medium, 10\% fetal bovine serum, glutamine, nonessential amino acids, penicillin, streptomycin) to $3.5-\mathrm{cm}$ tissue culture plates $16 \mathrm{hr}$ before starting the transfection.

2. For each transfection, add an optimized amount of LipofectACE (generally $\sim 3-10 \mu \mathrm{l}$ ) to $100 \mu \mathrm{l}$ of serum-free medium (Opti-MEM, Life Technologies/GIBCO-BRL cat. no. 31985-021), mix gently, and hold at room temperature for $5 \mathrm{~min}$. The optimal amount of LipofectACE and DNA, as well as the media and the confluence of COS-7 cells used, should be optimized according to the supplier's recommendations.

3. For each transfection, place 1-2 $\mu \mathrm{g}$ of DNA from the plasmid DNA isolation into $100 \mu \mathrm{l}$ of serum-free medium.

4. To form DNA-LipofectACE complexes, combine the two solutions prepared in steps 2 and 3, mix gently, and hold for $15 \mathrm{~min}$ at room temperature.

5. Prepare the COS-7 cells for transfection by aspirating the supplemented DMEM from the tissue culture plates, adding $1 \mathrm{ml}$ of Opti-MEM to each plate, and incubating for $5 \mathrm{~min}$ at $37^{\circ} \mathrm{C}$ in $5 \% \mathrm{CO}_{2}$.

6. After the DNA-LipofectACE complexes are formed, add $0.8 \mathrm{ml}$ of DMEM to each DNA-cationic lipid from step 4.

7. Remove the Opti-MEM from each plate.

8. Add one DNA-LipofectACE complex per plate.

9. Incubate $5-6 \mathrm{hr}$ at $37^{\circ} \mathrm{C}$ in a $5 \% \mathrm{CO}_{2}$ incubator.

10. Remove the DNA-LipfectACE complexes by aspiration, and add $2 \mathrm{ml}$ of supplemented DMEM to each plate.

11. Incubate for $16 \mathrm{hr}$ at $37^{\circ} \mathrm{C}$ in a $5 \% \mathrm{CO}_{2}$ incubator before isolating total RNA. The plates will become nearly $100 \%$ confluent after $16 \mathrm{hr}$ growth.

\section{Preparation of Total RNA}

The following procedure uses TRIzol reagent (Life Technologies/GIBCO-BRL cat. no. 15596-026), a monophasic solution of phenol and guanidine isothiocyanate; it maintains the integrity of RNA, while disrupting cells and dissolving cell components. ${ }^{(24,25)}$ Note: Do not wash the cells prior to adding the TRIzol reagent.

1. Aspirate medium from well.

2. Add $1 \mathrm{ml}$ of TRIzol reagent per $3.5-\mathrm{cm}$ well.

3. Pass the cell lysate several times through a pipette and transfer to an autoclaved microcentrifuge tube.

4. Hold the sample for $5 \mathrm{~min}$ at room temperature.

5. Add $0.2 \mathrm{ml}$ of chloroform per $\mathrm{ml}$ of TRIzol reagent and mix vigorously for $15 \mathrm{sec}$. 
6. Hold the sample for $2-3 \mathrm{~min}$ at room temperature.

7. Centrifuge at $12,000 \mathrm{~g}$ for $15 \mathrm{~min}$ at $4^{\circ} \mathrm{C}$.

8. Transfer the upper aqueous phase containing the RNA to a fresh tube.

9. Add $0.5 \mathrm{ml}$ of isopropanol per $\mathrm{ml}$ of TRIzol reagent originally added and mix well.

10. Hold for 5-10 $\mathrm{min}$ at room temperature.

11. Centrifuge at $12,000 \mathrm{~g}$ for $10 \mathrm{~min}$ at $4^{\circ} \mathrm{C}$. The RNA forms a gel-like pellet on the side and bottom of the tube.

12. Remove the supernate.

13. Add at least $1 \mathrm{ml}$ of $75 \%$ ethanol per $\mathrm{ml}$ of TRIzol reagent originally added and mix well.

14. Centrifuge at $12,000 \mathrm{~g}$ for $5 \mathrm{~min}$ at $4^{\circ} \mathrm{C}$.

15. Air dry the pellet. Note: Avoid drying completely to enhance subsequent solubilization.

16. Dissolve the RNA in $50 \mu$ l of DEPC-treated distilled water. A 5-min incubation at $50^{\circ} \mathrm{C}$ followed by a bried vortexing is recommended. RNA yields of $40-50 \mu \mathrm{g}$ per $3.5-\mathrm{cm}$ well are obtained.

\section{First-strand CDNA Synthesis}

The cDNA synthesis reaction is catalyzed by SuperScript II RNase $\mathrm{H}^{-}$Reverse Transcriptase (SuperScript II RT). This enzyme has been modified to eliminate the RNase $\mathrm{H}$ activity (normally present in reverse transcriptases) that degrades mRNA during first-strand cDNA synthesis. The use of this enzyme results in higher yields of cDNA. ${ }^{(26)}$ Because SuperScript II RT is not inhibited significantly by ribosomal and transfer RNA, it may be used effectively to synthesize cDNA from a total RNA preparation. The residual RNA should be stored at $-20^{\circ} \mathrm{C}$ or $-70^{\circ} \mathrm{C}$.

In preparation for first-strand cDNA synthesis, set up a program on a thermal cycler that will run for $10 \mathrm{~min}$ at $70^{\circ} \mathrm{C}, 30 \mathrm{~min}$ at $42^{\circ} \mathrm{C}$, and $15 \mathrm{~min}$ at $55^{\circ} \mathrm{C}$. Preheat the cycler to $70^{\circ} \mathrm{C}$ and hold. Alternatively, water baths may be used for the following procedures:

1. Add the following components to a microcentrifuge tube: $1 \mu$ l of oligonucleotide SA2 $(20 \mu \mathrm{M})$; RNA (1-3 $\mu \mathrm{g})$; DEPC-treated water (to a final volume of $12.0 \mu \mathrm{l}$ ).

2. Incubate the mixture for $5 \mathrm{~min}$ at $70^{\circ} \mathrm{C}$; place on ice for $1 \mathrm{~min}$. Collect the contents of the tube by a brief centrifugation and add the following components at room temperature: $4 \mu \mathrm{l}$ of $5 \times$ first strand buffer; $2 \mu l$ of $0.1 \mathrm{M}$ DTT; $1 \mu \mathrm{l}$ of $10 \mathrm{~mm}$ dNTP.

3. Mix gently, centrifuge briefly, and incubate for $2 \mathrm{~min}$ at $42^{\circ} \mathrm{C}$.

4. Add $1 \mu \mathrm{l}$ (200 units) of SuperScript II RT per reaction, mix gently, and incubate for $30 \mathrm{~min}$ at $42^{\circ} \mathrm{C}$ (Life Technologies/GIBCO-BRL cat. no. 18064014).

5. Incubate for $5 \mathrm{~min}$ at $55^{\circ} \mathrm{C}$.

6. Add $1 \mu \mathrm{l}$ ( 2 units) of RNase $\mathrm{H}$, mix gently, and incubate for $10 \mathrm{~min}$ at $55^{\circ} \mathrm{C}$. RNase $\mathrm{H}$ (Life Technologies/GIBCO-BRL cat. no. 18021-014) digestion is conducted at a temperature at which RT is inactive. This eliminates the possible synthesis of snap-back structures and second-strand products.

7. Collect the reverse transcription reaction mixture by a brief centrifugation and place on ice. Remove $5 \mu \mathrm{l}$ for the primary PCR amplification described below.

\section{Primary PCR}

In this portion of the protocol, the first-strand CDNA is amplified by PCR using vector-directed oligonucleotides. Following six cycles of amplification, 


\section{IIIIIIManual Supplement}

the reaction mixture is digested with $B s t \mathrm{XI}$, resulting in the elimination of two classes of background. PCR product background can result from pSPL3derived molecules that contain only vector sequences or from products resulting from use of the cryptic splice donor (Fig. 2). Vector-only mRNA molecules arise from pSPL3 subclones that contain partial or alternatively spliced exons, exons in the antisense orientation, introns, or from subclones that do not contain an insert. Vector-only mRNA containing the BstXI site is generated via the pairing of the vector splice donor and acceptor sequences. These molecules are converted into cDNA, made double-stranded, and digested with BstXI to greatly reduce the entry of vector-only molecules into the secondary PCR reaction. This permits a higher complexity of DNA to be used per transfection than with the original vector, pSPL1. ${ }^{(12)}$ pSPL3 also contains $B s t X I$ sites at either end of the multiple cloning site. Digestion with BstXI at these sites results in reduction of products that result from the utilization of the cryptic splice donor site. Normally, when an exon is trapped, the MCS is spliced out, unless the cryptic splice donor site located 3' to the MCS is used (Fig. 2).

1. Add the following components to a $0.5-\mathrm{ml}$ tube (this reaction and the secondary reaction can be scaled down to $10 \mu \mathrm{l}$ using $0.2-\mathrm{ml}$ tubes): $5 \mu \mathrm{l}$ of first-strand cDNA reaction; $5 \mu \mathrm{l}$ of $10 \times$ Taq DNA polymerase buffer; $1.5 \mu \mathrm{l}$ of $50 \mathrm{mM} \mathrm{MgCl} ; 1 \mu \mathrm{l}$ of $10 \mathrm{mM}$ dNTP; $2 \mu \mathrm{l}$ of oligonucleotide SA2 $(20 \mu \mathrm{M}) ; 2 \mu \mathrm{l}$ of oligonucleotide SD6 $(20 \mu \mathrm{M})$. Sterile water to a final volume of $49.5 \mu \mathrm{l}$.

2. Mix the contents of the tube and overlay with a drop of mineral oil.

3. Place the tube in a thermal cycler that has been preheated to $94^{\circ} \mathrm{C}$ and incubate for $5 \mathrm{~min}$.

4. Reduce the temperature to $80^{\circ} \mathrm{C}$ and hold; add 2.5 units of Taq DNA polymerase.

5. PCR as follows: six cycles $\left(1 \mathrm{~min}\right.$ at $94^{\circ} \mathrm{C}, 1 \mathrm{~min}$ at $60^{\circ} \mathrm{C}$, and $5 \mathrm{~min}$ at $\left.72^{\circ} \mathrm{C}\right) ; 1$ cycle $\left(10 \mathrm{~min}\right.$ at $\left.72^{\circ} \mathrm{C}\right)$.

6. Hold reactions at $55^{\circ} \mathrm{C}$, add 25 units of BstXI to each, and incubate overnight at $55^{\circ} \mathrm{C}$. BstXI restricts the DNA in $1 \times$ PCR buffer.

7. Add 5 units of BstXI to each reaction and incubate for $2 \mathrm{hr}$ at $55^{\circ} \mathrm{C}$.

\section{Secondary PCR}

1. Add the following components to a $0.5-\mathrm{ml}$ microcentrifuge tube: $5 \mu \mathrm{l}$ of BstXI-treated primary PCR product; $4.5 \mu \mathrm{l}$ of $10 \times \mathrm{Taq}$ DNA polymerase buffer; $1.5 \mu \mathrm{l}$ of $\mathrm{MgCl}_{2} ; 1 \mu \mathrm{l}$ of $10 \mathrm{mM}$ dNTP; $1 \mu \mathrm{l}$ of oligonucleotide dUSA4 $(20 \mu \mathrm{M})$; $1 \mu \mathrm{l}$ of oligonucleotide dUSD2 $(20 \mu \mathrm{M})$. Sterile water to a final volume of 49.5 $\mu$ l. Note: An increased final yield has been observed when twice as much primer is used in the first PCR as the second.

2. Mix the contents of the tube and overlay with a drop of mineral oil.

3. Place the tube in a thermal cycler, and bring the temperature to $94^{\circ} \mathrm{C}$ for 5 min.

4. Lower the temperature to $80^{\circ} \mathrm{C}$, hold, and add 2.5 units of Taq DNA polymerase.

5. PCR as follows: 30 cycles $\left(1 \mathrm{~min}\right.$ at $94^{\circ} \mathrm{C}, 1 \mathrm{~min}$ at $60^{\circ} \mathrm{C}$, and $3 \mathrm{~min}$ at $\left.72^{\circ} \mathrm{C}\right) ; 1$ cycle $\left(10 \mathrm{~min}\right.$ at $\left.72^{\circ} \mathrm{C}\right)$.

6. Electrophorese $3-5 \mu \mathrm{l}$ of each reaction on a $2 \%$ agarose gel to identify which reactions contain potential internal exons.

\section{Cloning the Secondary PCR Products}

There are several methods for cloning PCR products, including incorporation of restriction enzyme sites in the oligonucleotides, TA cloning, or using uracil DNA glycosylase (UDG) and modified primers. ${ }^{(21)}$ The UDG cloning proce- 
dure is preferred because it takes about $30 \mathrm{~min}$, avoids the risk of inefficient restriction digestion, cutting of restriction sites within an exon, and the inconsistent performance of TA cloning.

1. Add the following components to a microcentrifuge tube: 1-2 $\mu$ l of secondary PCR product (100 ng); $2 \mu$ l of pAMP10 cloning vector (50 ng); $1 \mu \mathrm{l}$ of $10 \times$ Taq DNA polymerase buffer; $1 \mu$ l of UDG (1 unit); Distilled water to a final reaction volume of $10 \mu l$.

2. Mix; incubate $30 \mathrm{~min}$ at $37^{\circ} \mathrm{C}$.

3. Transform $100 \mu \mathrm{l}$ of competent $E$. coli cells with $5 \mu \mathrm{l}$ of the annealing reaction and plate on $\mathrm{LB}$ plus ampicillin.

\section{Evaluation of Transformants by Colony PCR}

This is a rapid method to determine the size of the PCR product that has been cloned.

1. Pick each colony into $50 \mu \mathrm{l}$ of the following solution in a $0.5-\mathrm{ml}$ tube (this procedure can also be scaled done to $10 \mu \mathrm{l}$ using 0.2-ml tubes): $5 \mu \mathrm{l}$ of $10 \times$ Taq DNA polymerase buffer; $1.5 \mu \mathrm{l}$ of $\mathrm{MgCl}_{2} ; 1 \mu \mathrm{l}$ of $10 \mathrm{mM} \mathrm{dNTP} ; 1 \mu \mathrm{l}$ of oligonucleotide dUSA4 $(20 \mu \mathrm{M}) ; 1 \mu$ l of oligonucleotide dUSD2 $(20 \mu \mathrm{M}) ; 0.5$ $\mu \mathrm{l}$ of Taq DNA polymerase ( 2.5 units). Sterile water to a final volume of $50 \mu \mathrm{l}$.

2. Place a drop of mineral oil on each sample.

3. Place tubes in a thermal cycler preheated to $94^{\circ} \mathrm{C}$ and hold for $5 \mathrm{~min}$.

4. PCR as follows: 30 cycles $\left(45 \mathrm{sec}\right.$ at $94^{\circ} \mathrm{C}, 30 \mathrm{sec}$ at $55^{\circ} \mathrm{C}$, and $1 \mathrm{~min}$ at $\left.72^{\circ} \mathrm{C}\right) ; 1$ cycle $\left(10 \mathrm{~min}\right.$ at $\left.72^{\circ} \mathrm{C}\right)$.

5. Analyze PCR products on a $2 \%$ agarose gel.

The presence of a faint band at $177 \mathrm{bp}$ results from the amplification of pSPL3 sequences; however, bands larger than 177 bp should be analyzed because they may contain internal exons.

\section{Internal Exon Confirmation and Further Uses}

After cloning candidate internal exons, there are a number of steps that should be taken to eliminate some common forms of background, including Alu and HIV-tat sequences. For convenience, individual colonies should be picked and stored in 96-well microtiter dishes; this increases the speed with which a large number of subclones can be screened for the presence of repetitive sequences such a Alu in human and B1 in the mouse. Colonies are propagated and stored in arrays that can be replicated onto filters and subsequently tested by hybridization to labeled high-molecular weight human or mouse Cot-1 DNA. A filter set should be hybridized against labeled HIV-tat intronic sequence (a template for labeling can be generated by PCR amplification of the intronic region of pSPL3). Following identification of repetitive and HIV-tat sequences, pairwise hybridization of filters containing candidate internal exons against labeled colony PCR-amplified candidate clones will rapidly identify a minimal set of clones that can be hybridized to a filter containing either yeast chromosomes or total yeast DNA that has been digested, electrophoresed, and transferred to a filter. Following elimination of yeast sequences, the minimal set can be sequenced and GenBank can be checked using BLAST. ${ }^{(27)}$ The BLAST search will not only eliminate those clones that may be derived from the YAC cloning vector, but it will identify sequences in the DNA or protein sequence data base that the internal exon trapping protocol may have identified.

A critical step after the elimination of the various forms of background is determining whether a putative exon is expressed as part of an mRNA molecule. This can be accomplished in one of several ways, including zoo blotting, Northern blotting, or RT-PCR. Expressed sequences tend to be con- 


\section{IIIIIIManual Supplement}

served among related species; therefore, a human exon may hybridize to primate, bovine or even rodent DNA. A zoo blot is therefore a useful indicator of whether a sequence is expressed or not. A more rigorous test for expression, however, is provided by Northern blot analysis. Alternatively, if oligonucleotides are made to a putative exon, positive RT-PCR results can provide a definitive answer. Once a source of RNA is obtained in which a novel exon is expressed, the cDNA sequence can be lengthened using RACE or used as a hybridization probe to directly screen a cDNA library to obtain a full-length cDNA.

\section{TRAPPING 3'-TERMINAL EXONS USING PTAG4}

Most genes contain only one or at most a few 3 '-terminal exons. This is in contrast to the number of internal exons a gene can contain. Very large genes can have a surprisingly large number of internal exons. For example, the number of exons from the dystrophin gene is $79 .{ }^{(28)} 3$ '-Terminal exons also tend to be larger than internal exons, ${ }^{(29)}$ and therefore make better hybridization probes than internal exons. The protocol described here is based on the analysis of a cosmid clone; however, this method can be adapted for the analysis of other (P1, YAC, etc.,) cloned DNAs. Recent improvements in the procedure, including DNase I treatment of COS-7 RNA and restriction digestion after primary PCR, result in a significant increase in the efficiency of $3^{\prime}$ exon capture.

3'-Terminal exon trapping, like internal exon trapping, consists of four operations: subcloning cloned genomic DNA, transfecting the subcloned DNA into COS-7 cells, purifying the mRNA from the COS-7 cells, RT-PCR with vector-directed oligonucleotide primers, and UDG cloning. The procedure is depicted in Figure 3. Note that 3 '-terminal exons are trapped because they provide flanking splice acceptor and poly $(\mathrm{A})^{+}$signals. This is in contrast to internal exon trapping, which captures sequences flanked by a splice donor and splice acceptor.

\section{Subcloning into pTAG4}

pTAG4 contains a multiple cloning site that can be uniquely cut with a variety of restriction endonucleases (see Fig. 4). For subcloning, the vector should be linearized, dephosphorylated, and ligated to the target genomic DNA. To test for the presence of functional 3'-terminal exons, either individual subclones or pools of subclones can be used. Use the same protocols to prepare vector and target DNA as described above of for internal exon trapping. When subcloning human or mouse genomic DNA that is cloned in a vector that uses ampicillin resistance for selection, digested genomic DNA clones should be dephosphorylated and ligated into linearized (nondephosphorylated) pTAG4. Alternatively, one can purify the vector away from the insert or choose an enzyme that will inactivate the ampicillin resistance gene (e.g., PvuI). Otherwise, a major fraction of the subclones will be religated genomic vector or pTAG4 containing additional copies of the $\beta$-lactamase gene from the starting vector. ${ }^{(30)}$

\section{Ligation and Transformation: Shotgun Subcloning of Cosmid DNA into PTAG4}

1. Add distilled water to the following components for a final volume of 5 $\mu \mathrm{l}$ : 50-100 ng of pTAG4 restriction enzyme-digested DNA; 100-200 ng of restriction enzyme-digested cosmid DNA; $1 \mu$ l of $5 \times$ of T4 DNA ligase buffer; $0.5 \mu \mathrm{l}$ (at least 0.5 unit) of T4 DNA ligase. Final volume of $5 \mu$ l. Include a 


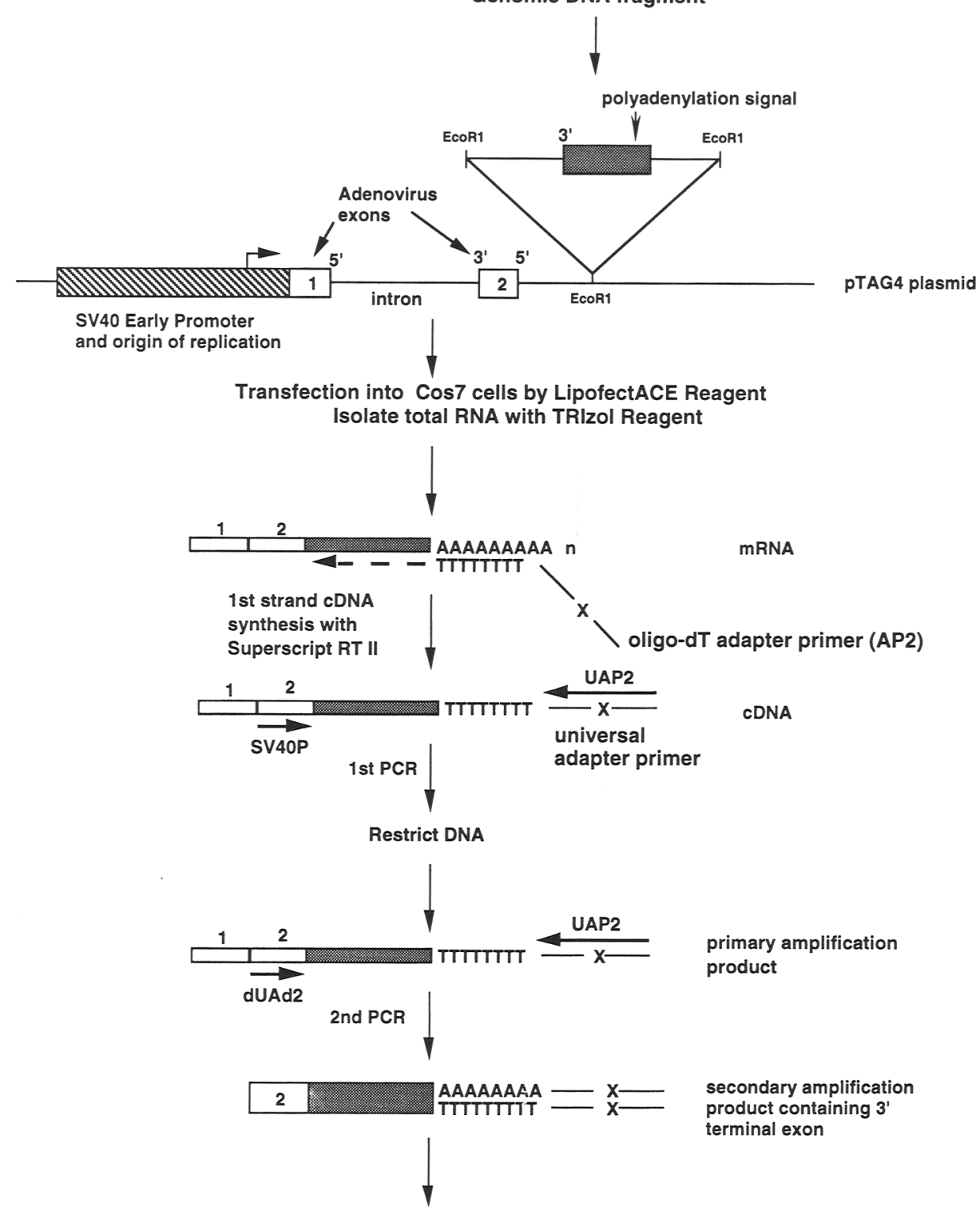

UDG clone into PAMP1

FIGURE 3 Flow diagram of 3 '-terminal exon trapping of a cosmid using pTAG4. YAC DNA is digested with a restriction enzyme, e.g., EcoRI. In this example, a single exon (shaded box) is contained in an EcoRI fragment. The exon is flanked by splicing acceptor ( $\left.3^{\prime}\right)$ and polyadenylation sites. The pTAG4 vector is prepared for subcloning at the same restriction site. The MCS of pTAG4 contains 38 restriction enzyme sites. After subcloning genomic DNA into pTAG4, DNA is isolated and transfected into COS-7 cells. Total RNA is isolated and treated with DNase I before RNA-based PCR analysis. After generation of cDNA with adapter primer AP2 (AAG GAT CCG TCG ACA TC $(T)_{17}$, the first round of PCR is performed using the outside primer pair UAP2 (CUA CUA CUA CUA AAG GAT CCG TCG ACA TC) and SV40P (AGC TAT TCC AGA AGT AGT GA) followed by restriction digestion. A second round of PCR is performed using primer UAP2 and the nested primer dUAd2 (CAU CAU CAU CAU CAG TAC TCT TGG ATC GGA) to provide specificity and to install DNA sequences that allow UDG cloning of the PCR products. Trapped exons are recognized after gel analysis of the PCR products.

control (all the above components without cosmid DNA) to assess the level of vector self-ligation.

2. Mix gently and incubate for $1 \mathrm{hr}$ at room temperature.

3. Transform $E$. coli with the ligated DNA. 
4. Recover DNA by the plate scraping method described above from at least 100 colonies for every cosmid to be tested. Note: The efficiency of the shotgun subcloning can be assessed by cutting the pTAG4 library DNA with the same restriction enzyme that was used to subclone it and comparing it with the digested cosmid DNA by agarose gel electrophoresis.

5. Plate 0.1 and $0.01 \mathrm{ml}$ of each transformation on LB plus ampicillin to assess the degree of vector religation. Repreparation of the dephosphorylated vector is recommended if the nonrecombinant frequency is $>10 \%$.

The methods for COS-7 transfection and preparation of total RNA are the same as those used for the internal exon trapping method described above. Include mock and pTAG4 DNA transfections as controls.

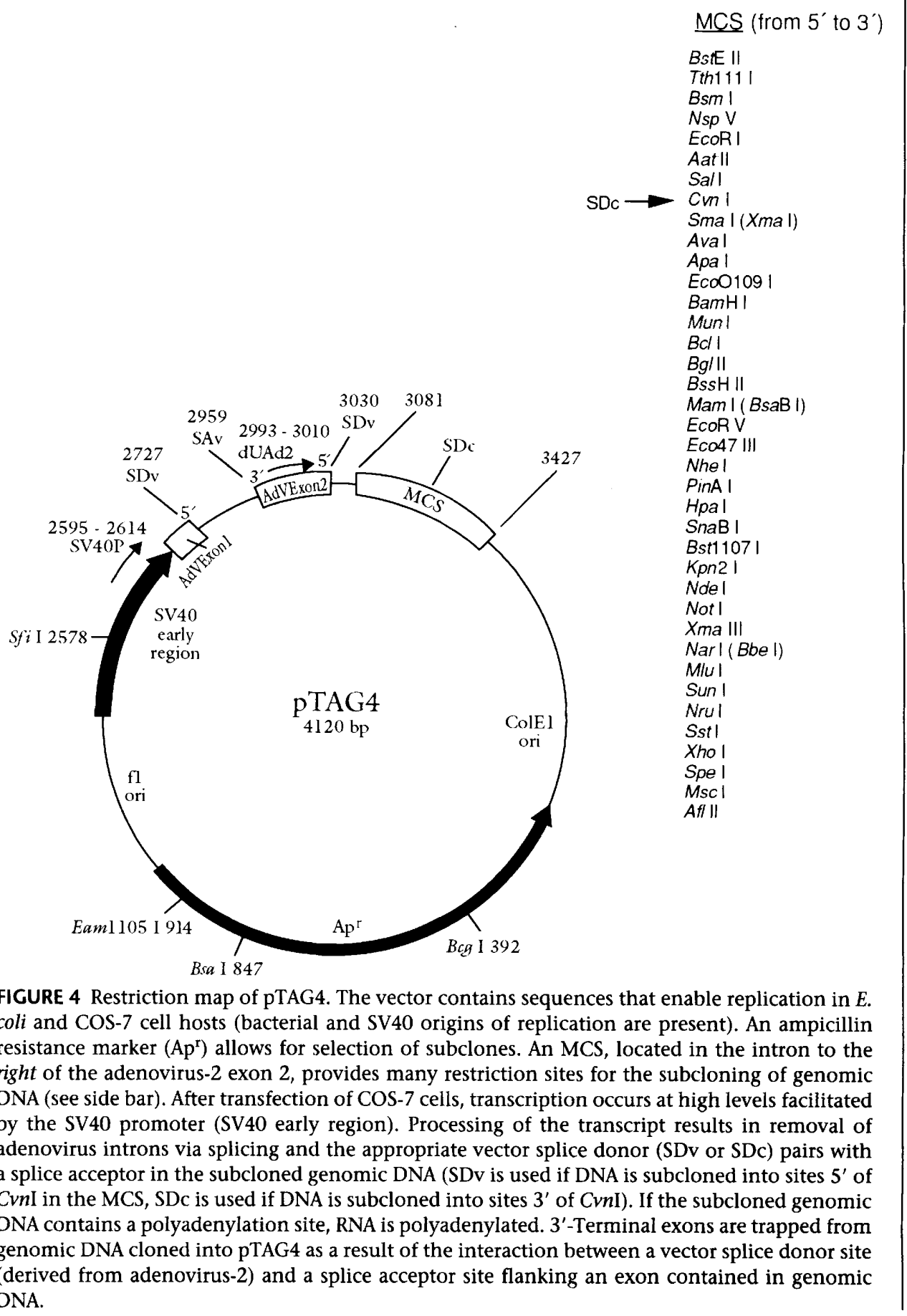




\section{DNase I Treatment}

DNase I treatment of total RNA in combination with restriction digestion following the first PCR (see below) eliminates the major form of background that has been observed using the trapping vector pTAG4 (P.E. Nisson, unpubl.).

1. Resuspend RNA from a $3.5-\mathrm{cm}$ dish $\left(\sim 10^{6}\right.$ cells $)$ in $50 \mu$ l of DEPC-treated water.

2. Combine $17 \mu \mathrm{l}$ of the RNA with $2 \mu \mathrm{l}$ of $10 \times$ DNase I buffer and $1 \mu \mathrm{l}$ of DNase I (Life Technologies/GIBCO-BRL cat. no. 18068-015).

3. Incubate at room temperature for $30 \mathrm{~min} ; 65^{\circ} \mathrm{C}$ for $5 \mathrm{~min}$.

4. Phenol/chloroform extract, ethanol precipitate, wash with $70 \%$ ethanol, dry, and resuspend in $17 \mu$ l of DEPC-treated water.

\section{CDNA Synthesis}

RNA samples that provide positive signals can be useful as controls for cDNA synthesis and primary PCR. (For more information about SuperScript RT II, see First-Strand cDNA Synthesis, above).

1. Add the following components to a microcentrifuge tube:

\begin{tabular}{ll} 
Component & Amount \\
\hline Adapter primer $(\mathrm{AP} 2 ; 10 \mu \mathrm{M})$ & $2 \mu \mathrm{l}$ \\
RNA & $1-3 \mu \mathrm{g}$ \\
DEPC-treated water & to a final volume of $12 \mu \mathrm{l}$
\end{tabular}

2. Incubate the mixture for $5 \mathrm{~min}$ at $70^{\circ} \mathrm{C}$ to denature the RNA and chill for $1 \mathrm{~min}$ on ice. Collect the contents of the tube by brief centrifugation and add the following components:

Component

$5 \times$ first strand buffer

$0.1 \mathrm{M}$ DTT

$10 \mathrm{mM}$ dNTP mix
Volume $(\mu l)$

4

2

1

3. Mix gently and collect the solution by brief centrifugation. Incubate for 2 min at $42^{\circ} \mathrm{C}$.

4. Add $1 \mu \mathrm{l}$ (200 units) of SuperScript II RT, mix gently, and incubate for $30 \mathrm{~min}$ at $42^{\circ} \mathrm{C}$ (Life Technologies/GIBCO-BRL cat. no. 18064-014).

5. Incubate for $5 \mathrm{~min}$ at $55^{\circ} \mathrm{C}$.

6. Add $1 \mu \mathrm{l}$ of RNase $\mathrm{H}$, mix gently, and incubate for $10 \mathrm{~min}$ at $55^{\circ} \mathrm{C}$. Note: RNase $\mathrm{H}$ digestion is conducted at a temperature at which SuperScript II RT is inactive. This eliminates the possible synthesis of snap-back structures and second-strand products.

7. Collect the reverse transcription reaction mixture by brief centrifugation and place on ice. Remove $1 \mu l$ for the primary PCR amplification.

\section{Primary PCR}

1. Add the following components to a microcentrifuge tube:

Component

Volume $(\mu \mathrm{l})$

RT reaction mixture

$10 \times$ Taq buffer (500 mM KCl, $100 \mathrm{~mm}$ Tris at $\mathrm{pH} 8.3$ )

$50 \mathrm{mM} \mathrm{MgCl}_{2}$

$10 \mathrm{~mm}$ dNTP mix

Oligonucleotide SV40P $(10 \mu \mathrm{M})$

Universal amplification primer (UAP2; $10 \mu \mathrm{M}$ )

Distilled water 
2. Mix the contents of the tube and overlay with a drop of mineral oil.

3. Place the tube in a thermal cycler that has been preheated to $94^{\circ} \mathrm{C}$ and incubate for $5 \mathrm{~min}$.

4. Reduce the temperature to $80^{\circ} \mathrm{C}$ and pause; then add 2.5 units $(0.5 \mu l)$ of Taq DNA polymerase per tube.

5. Perform 10 cycles of PCR amplification as follows: Denature $94^{\circ} \mathrm{C}$ for 45 sec; anneal $55^{\circ} \mathrm{C}$ for $45 \mathrm{sec}$; extend $72^{\circ} \mathrm{C}$ for $1 \mathrm{~min}$.

6. Incubate for an additional $10 \mathrm{~min}$ at $72^{\circ} \mathrm{C}$ and then hold the reaction at $4^{\circ} \mathrm{C}$.

\section{Restriction Digestion of Primary PCR Reaction}

A second modification to the original protocol for 3 '-terminal exon trapping is restriction enzyme digestion following the first PCR. ${ }^{(18)} \mathrm{A}$ major form of background, presumably derived from the contamination of the COS-7 RNA with pTAG4 subclone DNA, can be controlled by two treatments: (1) DNase I treatment of RNA and (2) restriction enzyme digestion following the first PCR (P.E. Nisson, unpubl.). If the intervening sequence from the pTAG4 vector is present, then the restriction site that was used for subcloning will also be present and susceptible to restriction cleavage. This cleavage will prevent these molecules from being amplified.

1. Combine $17 \mu \mathrm{l}$ of the primary PCR reaction with $2 \mu \mathrm{l}$ of the appropriate $10 \times$ restriction enzyme buffer and $1 \mu$ l of the restriction enzyme used for subcloning into pTAG4.

2. Incubate for $1 \mathrm{hr}$ at $37^{\circ} \mathrm{C}$, dilute the reaction to $170 \mu \mathrm{l}$ with water, and use $1 \mu \mathrm{l}$ of this for the secondary PCR reaction.

\section{Secondary PCR}

There are two reasons for performing this reaction: (1) the secondary PCR amplification uses a primer (dUAd2) that is nested $3^{\prime}$ to SV40P, which helps ensure the specificity of the amplified exons, and (2) the secondary primers contain dUMP residues for efficient directional UDG cloning into the pAMP1 vector. ${ }^{(21)}$

1. Add the following components to a $0.5-\mathrm{ml}$ microcentrifuge tube:

Component

Primary PCR reaction

$10 \times$ Taq buffer

$50 \mathrm{~mm} \mathrm{MgCl}_{2}$

$10 \mathrm{mM}$ dNTP mix

UAP2 $(10 \mu \mathrm{M})$

Oligonucleotide dUAd2 (10 $\mu \mathrm{M})$

Distilled water
Volume $(\mu 1)$

1

5

1.5

1

2

2

37.5

2. Mix the contents of the tube and overlay with a drop of mineral oil.

3. Place the tube in a thermal cycler that has been preheated to $94^{\circ} \mathrm{C}$ and incubate for $5 \mathrm{~min}$.

4. Lower the temperature to $80^{\circ} \mathrm{C}$, pause, and add 2.5 units $(0.5 \mu \mathrm{l})$ of $\mathrm{Taq}$ DNA polymerase per tube.

5. Perform 30 cycles of PCR amplification as follows: Denature $94^{\circ} \mathrm{C}$ for 45 sec; anneal $55^{\circ} \mathrm{C}$ for $45 \mathrm{sec}$; extend $72^{\circ} \mathrm{C}$ for $1 \mathrm{~min}$.

6. Incubate for an additional $10 \mathrm{~min}$ at $72^{\circ} \mathrm{C}$ and then hold the reaction at $4^{\circ} \mathrm{C}$. 
Agarose Gel Electrophoresis and Analysis of Secondary PCR Products Electrophorese at least $3 \mu \mathrm{l}$ of each reaction in a $2 \%$ agarose gel. Compare the PCR products in the experimental lanes with the pTAG4 and mock transfection lanes. Occassionally, a faint pTAG4 PCR product may appear as an $\sim 0.9$ $\mathrm{kb}$ band with a smear. Also, in some cases, products derived from COS-7 RNA will be seen. All products other than the pTAG4 and COS-7 products are potential 3' exons and can be subcloned into pAMP1; alternatively, individual PCR fragments can be isolated. PCR products can be reamplified, sized, and labeled for use as a hybridization probe using colony PCR.

\section{Cloning and Analyzing the Secondary PCR Products}

The same options described for internal exon trapping are available for the analysis of secondary PCR products after 3 '-exon trapping. After subcloning putative $3^{\prime}$ exons, sequence analysis can indicate whether the trapped sequences are real 3' exons. The first criterion is that one of the pTAG4 splice donors has paired with a splice acceptor that flanks novel sequence. The second criterion is observing one of the major polyadenylation signal sequences (AATAAA or ATTAAA) 10-30 nucleotides $5^{\prime}$ to the polyadenylation site. Finally, if a novel sequence is expressed as mRNA as shown by Northern blotting or RT-PCR, the case will be strengthened that a trapped sequence is a bona fide $3^{\prime}$ exon.

In summary, methods for capturing internal and 3 '-terminal exons are described. A procedure for trapping internal exons from YACs is presented, followed by a protocol for capturing 3 '-terminal exons from cosmid DNA. For the 3 '-terminal exon-trapping procedure, methods for DNase I treatment of RNA and restriction enzyme digestion following the primary PCR have been developed and shown to greatly reduce background. These improvements have been integrated into the 3 '-terminal exon-trapping protocol.

Note: Kits for internal (cat. no. 18449-017) and 3'-terminal exon trapping (cat. no. 18439-018) are available from Life Technologies/GIBCO-BRL, Inc.

\section{ACKNOWLEDGMENTS}

We acknowledge the supportive information provided by conversations with Alan Buckler, Deanna Church, Eric Green, David Krizman, and Michael North.

\section{REFERENCES}

1. Collins, F.S. 1992. Positional cloning: Let's not call it reverse anymore. Nature Genet. 1: 3-6.

2. Yokobata, K., B. Trenchak, and P.J. de Jong. 1991. Rescue of unstable cosmids by in vitro packaging. Nucleic Acids Res. 19: 403-404.

3. Pierce, J.C., B. Sauer, and N. Sternberg. 1992. A positive selection vector for cloning high molecular weight DNA by the bacteriophage P1 system: Improved cloning efficacy. Proc. Natl. Acad. Sci. 89: 2056-2060.

4. Ioannou, P.A., C.T. Amemiya, J. Garnes, P.M. Kroisel, H. Shizuya, C. Chen, M.A. Batzer, and P.J. de Jong. 1994. A new bacteriophage P1-derived vector for the propagation of large human DNA fragments. Nature Genet. 6: 84-89.

5. Shizuya, H., B. Birren, U. Kim, V. Mancino, T. Slepak, Y. Tachiiri, and M. Simon. 1992. Cloning and stable maintenance of 300-kilobase-pair fragments of human DNA in Escherichia coli using an F-factor-based vector. Proc. Natl. Acad. Sci. 89: 8794-8797.

6. Green, E.D., H.C. Riethman, J.E. Dutchik, and M.V. Olson. 1991. Detection and characterization of chimeric yeast artificial-chromosome clones. Genomics 11: 658-669.

7. Rommens, J.M., M.C. Iannuzzi, B.-S. Kerem, M.L. Drumm, G. Melmer, M. Dean, R. Rozmahel, J.L. Cole, D. Kennedy, N. Hidaka, M. Zsiga, M. Buchwald, J.R. Riordan, L.-C. Tsui, and F.S. Collins. 1989. Identification of the cystic fibrosis gene: Chromosome walking and jumping. Science 245: 1059-1065.

8. Elvin, P., G. Slynn, D. Black, A. Graham, R. Butler, J. Riley, R. Anand, and A.F. Markham. 1990. Isolation of cDNA clones using yeast artificial chromosome probes. Nucleic Acid Res. 18: 
3913-3917.

9. Bird, A. 1986. CpG-rich islands and the function of DNA methylation. Nature 321: 209-213.

10. Lovett, M., J. Kere, and L.M. Hinton. 1991. Direct selection: A method for the isolation of cDNAs encoded by large genomic regions. Proc. Natl. Acad. Sci. 88: 9628-9632.

11. Parimoo, S., S.R. Patanjali, H. Shulka, D.D. Chaplin, and S.M. Weissman. 1991. cDNA selection: Efficient PCR approach for the selection of cDNAs in large genomic DNA fragments. Proc. Natl. Acad. Sci. 88: 9623-9627.

12. Buckler, A.J., D.D. Chang, S.L. Graw, J.D. Brook, D.A. Haber, P.A. Sharp, and D.E. Housman. 1991. Exon amplification: A strategy to isolate mammalian genes based on RNA splicing. Proc. Natl. Acad. Sci. 88: 4005-4009.

13. Church D.M., C.J. Stotler, J.L. Rutter, J.R. Murrell, J.A. Trofatter, and A.J. Buckler. 1994. Isolation of genes from complex sources of mammalian genomic DNA using exon amplification. Nature Genet. 6: 98-105.

14. Auch, D. and M. Reth. 1990. Exon trap cloning: Using PCR to rapidly detect and clone exons from genomic DNA fragments. Nucleic Acids Res. 18: 6743-6744.

15. Duyk, G.M., S. Kim, R.M. Myers, and D.R. Cox. 1990. Exon trapping: A genetic screen to identify candidate transcribed sequences in cloned mammalian genomic DNA. Proc. Natl. Acad. Sci. 87: 8995-8999.

16. Hamaguchi, M., H. Sakamoto, H. Tsuruta, H. Sasaki, T. Muto, T. Sugimura, and M. Terada. 1992. Establishment of a highly sensitive and specific exon-trapping system. Proc. Natl. Acad. Sci. 89: 9779-9783.

17. Ozawa, N., T. Kano, C. Taga, M. Hattori, Y. Sakaki, and J. Suzuki. 1993. An exon-trapping system with a newly constructed trapping vector pEXT2; its application to the proximal region of the human chromosome 21 long arm. FEBS Lett. 325: 303-308.

18. Krizman, D.B. and S.M. Berget. 1993. Efficient selection of 3 '-terminal exons from vertebrate DNA. Nucleic Acids Res. 21: 5198-5202.

19. Nisson, P.E. and P.C. Watkins. 1994. Isolation of exons from cloned DNA by exon trapping. In Current protocols in human genetics, vol. 1 (ed. N.C. Dracopoli, J.L. Haines, B.R. Korf, D.T. Moir, C.C. Morton, C.E. Seidman, J.G. Seidman and D.R. Smith), pp. 6.1.1-6.1.14. John Wiley $\&$ Sons, New York.

20. Gibson, F., H. Lehrach, A.J. Buckler, S.D.M. Brown, and M.A. North. 1994. Isolation conserved sequnces from yeast artificial chromosomes by exon amplification. BioTechniques 16: 453-459.

21. Nisson, P.E., A. Rashtian, and P.C. Watkins. 1991. Rapid and efficient cloning of Alu-PCR products using uracil DNA glycosylase. PCR Methods Applic. 1: 120-123.

22. Moore, D. 1987. Minipreps of plasmid DNA. In Current protocols in molecular biology, vol. 1 (ed. F.M. Ausubel, R. Brent, R.E. Kingston, D. Moore, J.G. Seidman, J.A. Smith, and K. Struhl), pp. 1.6.2-1.6.4. John Wiley \& Sons, New York.

23. Rose, J.K., L. Buonocore, and M.A. Whitt. 1991 A new cationic liposome reagent mediating nearly quantitative transfection of animal cells. BioTechniques 10: 520-525.

24. Chomczynski, P. and N. Sacchi. 1987. Single-step method of RNA isolation by acid guanidinium thiocyanate-phenol-chloroform extraction. Anal. Biochem. 161: 156-159.

25. Simms, S., P.E. Cizdziel, and P. Chomczynski. 1993. TRIzol: A new reagent for optimal single-step isolation of RNA. Focus 15: 99-102.

26. Gerard, G.F., B.J. Schmidt, M.L. Kotewicz, and J.H. Campbell. 1992. cDNA synthesis by Moloney Murine Leukemia virus RNase $\mathrm{H}$-minus reverse transcriptase possessing full DNA polymerase activity. Focus 14: 91-93.

27. Altschul, S.F., W. Gish, W. Miller, E.W. Myers, and D.J. Lipman. 1990. Basic local alignment search tool. J. Mol. Biol. 215: 403-410.

28. Roberts, R.G., A.J. Coffey, M. Bobrow, and D.R. Bentley. 1992. Determination of the exon structure of the distal portion of the dystrophin gene by vectorette PCR. Genomics 13: 942950.

29. Hawkins, J.D. 1988. A survey on intron and exon lengths. Nucleic Acids Res. 16: 9893-9908.

30. Connors, T., T. Burn, and G. Landes. 1994. Exon trapping vector pSPL3-CAM: Improved shotgun subcloning of cosmid-derived fragments. Focus 16 (in press). 


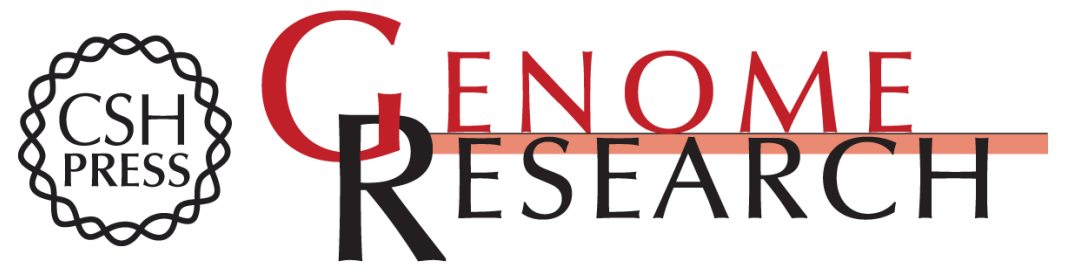

\section{Protocols for trapping internal and 3'-terminal exons.}

P E Nisson, A Ally and P C Watkins

Genome Res. 1994 4: S24-S39

References This article cites 27 articles, 8 of which can be accessed free at: http://genome.cshlp.org/content/4/1/S24.full.html\#ref-list-1

\section{License}

Email Alerting Receive free email alerts when new articles cite this article - sign up in the box at the Service top right corner of the article or click here.

\section{Affordable, Accurate Sequencing.}

To subscribe to Genome Research go to: https://genome.cshlp.org/subscriptions 